\title{
De-securitising 'the South in the North'? Gendered Narratives on the Refugee Flows in the European Mediascape
}

\author{
Rita Santos* \\ Sílvia Roque** \\ Sofia José Santos ${ }^{* * *}$
}

\begin{abstract}
This article focuses on media representations of 'the South in the North' crosscutting the European mediascape in 2015 and the beginning of 2016. Assuming that both identities and perceptions of in/security are socially constructed, particularly by means of discourse, that security is gendered and gender constructions are in turn built on dynamics of in/security, and that gendered power relations and representations are always entangled with other structures of inequality and domination such as racism, this article argues that gendered categories of othering in the media's representations have been critical to produce and justify 1) hegemonic narratives of securitisation that aim to protect an imagined European identity and 2) counter-narratives denouncing the racial and cultural discrimination tied to the 'North's' hegemonic representations of refugees. Theoretically, the article proposes a dialogue among critical, feminist, and postcolonial peace and security studies. Methodologically, it analyses through discourse analysis three highly mediatised cases by examining the social representations of the refugees, namely their gendered components put forward by representative European media outlets based in the UK. It explores their implications in terms of the consolidation of stereotypes and hierarchies of suffering according to criteria of credibility/suspicion and vulnerability/threat, and identifies some examples of media counter-narratives on refugee flows through specific gendered and racialised representations.
\end{abstract}

Keywords: Narratives; Gender; Race; Identity; Migrants and Refugees; Media; Securitisation.

\footnotetext{
* University of Coimbra, Coimbra, Portugal; rita@ces.uc.pt. ORCID iD 0000-0001-5174-4235.

** University of Coimbra, Coimbra, Portugal; silviar@ces.uc.pt. ORCID iD 0000-0002-7211-837X.

*** University of Coimbra, Coimbra, Portugal; sjs@ces.uc.pt. ORCID iD 0000-0001-9300-7452.
} 


\section{Introduction}

Between 2015 and 2016, we witnessed a significant increase in the number of refugees and migrants reaching Europe via the Mediterranean, largely due to the deterioration of the violent conflict in Syria. Data from the United Nations High Commissioner for Refugees (UNHCR, 2015: 7) indicate that approximately one million people (four times more than registered in 2014) reached the coastal regions of Europe, especially via Greece, and in lesser numbers via Italy, as a result of war and poverty. Most of these population fluxes originated in Syria, followed by countries such as Afghanistan and Iraq. 2015 was also the year when reporters registered the biggest cross-border population flow (White 2015), and responded to it with several news pieces, opinion pieces, in-depth reports and fora in European media.

Although these journeys were not new and most refugees were in fact hosted in neighbouring countries, during this period both European mainstream media and debates on online social media built a narrative framing these phenomena as a European 'crisis,' 1 that is, an extraordinary and exceptional event which particularly affected Europe as a result of its 'invasion' by southern population fluxes, either using a humanitarian frame, or a securitisation or militarisation one, underlining the risks and dangers that these fluxes entailed for Europe economically, socially, culturally and in terms of national/European security. These fluxes are frequently assumed to be putting the European 'body politic [...] in danger', which would then need to 'be eugenically preserved from hordes of aliens that, like a mortal disease, have to be eradicated from the healthy corpus of European nations' (Giuliani 2016: 4).

This article focuses on media representations of the recent refugee flows - 'the South in the North' - crosscutting the European mediascape in 2015 and the beginning of 2016. The first part of the article is divided into four sections. The first three sections present its main empirical and theoretical contributions, proposing a dialogue among critical, feminist, and postcolonial peace and security studies. We situate our analysis of the recent refugee flows in the European mediascape in the context of existing literature on media representations and the securitisation of refugee flows in the recent European context, and on gender, race, displacement and migration. By using the expression 'South in the North,' we allude not to specific geographic realities, but rather to the economically, socially and politically subjugated and racialised peoples within the borders of wealthier countries. The fourth section discusses the methodology that guided our discourse analysis. The second part of the article presents the key findings of our study. On the one hand, it examines the gendered and racialised tropes of the hegemonic media narratives on the 'refugee crisis' as stepping stones of the securitisation of these flows whose aim is to protect an imagined European identity and, on the other hand, it explores some media counter-narratives denouncing the racial and cultural discrimination tied to the 'North's' hegemonic representations of refugees. The article concludes by exploring the implications of these representations in terms of the consolidation of stereotypes and hierarchies of suffering according to criteria of credibility/suspicion and vulnerability/threat, and identifies a few 
examples of media counter-narratives on refugee flows through specific gendered and racialised representations.

\section{Building insecurity: discourse, media and identities}

\section{Security as discourse}

Despite a fundamental common ground of what 'security' means, different concepts and notions have emerged within policy circles and academic thinking highlighting that what one defines as a threat and what one understands as the security referent varies across cultures, time, space, and, most of all, locus of enunciation.

According to the Copenhagen School, security is a socially constructed, intersubjective and self-referential practice as it emerges 'not necessarily because an existential threat exists but because the issue is presented and framed as such' (Buzan et al. 1998: 24). It 'ultimately rests neither with the objects nor with the subjects but among the subjects' (Buzan et al. 1998: 31). This construction of (in)security is mainly produced by means of a process called securitisation (Buzan et al. 1998): a complex process which makes a specific issue/ideal/object/subject be labelled as a security issue that requires extraordinary measures. ${ }^{2}$ Above all, securitisation is an act of speech: when something or someone is labelled as security-related (even if not explicitly), he/she/it becomes precisely that for an audience (Buzan et al. 1998). Opposing the idea of securitisation lies the concept of desecuritisation, which synthesises the process through which a specific issue is moved away from the security agenda to that of normal politics, as it is no longer defined in terms of security (Buzan et al. 1998).

The construction of these narratives and choices does not occur spontaneously, however, nor within a discursive and ideological void (Barrinha 2011). It is a process that is created, sustained, and developed in a broader ideological and identitarian discursive structure in which it is embedded and that shapes and validates it.

Within securitisation/de-securitisation processes, the media perform a key functional role. By 'functional role' we refer to what the Copenhagen School of thought calls an actor which, voluntarily or not, 'significantly influences decisions in the field of security' (Buzan et al. 1998: 36). As what we conceive as reality is hardly - if ever - lived and perceived in an objective way, but rather through subjective images, narratives and representations that shape people's experiences and knowledge (Hall 1997), the media perform a decisive role within (de-)securitisation processes. By means of the use of discourse as verbal and non-verbal language (Moller 2007), the media can 'not only construct realities by shaping people's perceptions of the outside world, but [...] also constitute a constructed reality in their own right, with specific agendas and biases - both explicit or systemic' (Fleras and Kunz 2001: 47) - and which are framed upon and built - consciously or unconsciously to secure the dominant cultural, political and economic frameworks. On the audiences' side, the media emerge as reliable sources of reality as it is through these actors that the audiences reach out to realities, events, and geographies that they wouldn't otherwise be able to know (Shaw 1979). 


\section{Media and the securitisation of refugees}

Several studies have analysed the articulation between media representations and the securitisation of refugees in the recent European context. Most of them focus on the importance of words. For instance, the debates surrounding the labelling of the refugee crises and its constituents have taken centre stage in the literature that focused on the media representation of said phenomena. Controversies over the labelling of these populations as 'displaced people,' 'immigrants,' 'migrants', and 'refugees' (KhosraviNik 2010), as well as the labelling of the crises as 'the European refugee crisis,' 'the Mediterranean refugee crisis', or 'the Syrian refugee crisis' (Rajaram 2015) constitute examples of this. The choice of words used to define or characterise people either as migrants, as refugees or both can inspire different kinds of sentiments (refugee/solidarity, migrant/fear) and create different levels of legitimacy accorded to each category (Hoyer 2016; Holmes and Castañeda 2016). The use of the word 'crisis' suggests exceptionality, distancing, for example, this current influx of population from other population flows that have been central to the constitution of the European states and their economies and mobilising specific types of intervention outside the realm of normal politics (Rajaram 2015), whereas the reference to the crisis as a migrants' or refugees' crisis suggests that refugees are the problem, and Europe is thus presented as the problem-solver (Holmes and Castañeda 2016: 19; Colombo 2017: 5).

Additionally, some literature focused particularly on images, their subtexts and the imaginaries that they help to construct. For instance, while some found a 'recurrent representation of refugees as nomadic groups, and not as individuals, subordinated and at risk' (Empinotti 2017), which reinforces the findings from studies in other contexts such as Australia, where 'visual representations of refugees at border crossings en masse tend to have a depersonalising and criminalising effect' (Lenette and Miskovic 2016: 5), others examined more diverse and complex visual regimes (Chouliaraki and Stolic 2017).

Most studies, however, concur with the idea that media representations of refugees often oscillated between two subliminal scripts: victims and evil-doers (Chouliaraki and Stolic 2017), vulnerable and dangerous outsiders (Giorgiou and Zaborowski 2017: 1), the good and the bad refugee (Szcepanik 2016), the deserving and the undeserving (Holmes and Castañeda 2016). The studies also concur with the observation that these representations may activate different societal and political discourses on refugees that range from solidarity and acceptance to refusal and self-protection.

Nevertheless, research also shows that victimhood and threat should not be considered as two homogenous and completely opposite poles of representation of refugees and that societal and political discourses and actions also reflect the diversity and complexity of these entangled representations. For instance, Georgiou and Zaborowski (2017) and Berry, Garcia-Blanco and Moore (2015), who analysed different media across distinct European countries (United Kingdom, Italy, Spain, Hungary, Germany and Sweden) between 2015 and 2016, pointed to the existence of three different periods concerning the trends in media coverage of the 'refugee crisis.' The first took place between April and June 2015 and was defined by a greater number of references to the humanitarian repercussions of these flows, highlighting, for example, the number of people who died trying to cross the Medi- 
terranean; it also included articles focusing on the economic and cultural consequences of these flows to Europe. The second one took place between August and September 2015 and focused greatly on humanitarian actions and European solidarity movements led by civil societies, and which had their peak in the media coverage of Aylan Kurdi's death. The third one took place after the Paris terrorist attacks (November 2015) and was marked by the exponential growth of references to the geopolitical consequences which would arise from hosting these populations as well as references to defensive measures, including closing borders, reinforcing entry procedures, increased police and military presence at borders and reception centres, among others. Chouliaraki and Stolic (2017) identify five different 'regimes of visibility ${ }^{3}$ as providers of complex senses of responsibility. The authors stress that although the 'combination of empathy with suspicion is an established pattern in the representation of human mobility' (Chouliaraki and Stolic 2017: 2), the audiences' engagement with the stories 'is not exhausted to those two inherently deficient options: comfortable familiarity with the refugees' sameness or fear of their radical otherness', but are in fact frequently intertwined with 'a wider range of performances for civic agency' such as 'monitorial citizenship, tender-hearted benevolence, vigilant nationalism, cosmopolitan activism or self-reflexive confession' (Chouliaraki and Stolic 2017: 12).

Several authors seem to agree that beyond this apparent dichotomy in representations, at least two recurring trends must be highlighted. The first one concerns the dehumanisation of refugees. This dehumanisation is operated though different mechanisms such as the lack of refugee voices and the lack of proper and deep contextualisation (Berry, Garcia-Blanco and Moore 2015; Georgiou and Zaborowski 2017; Chouliaraki and Zaborowski 2017) or by portraying them either as passive, agentless victims or as a threatening multitude.

The second process concerns the othering of refugees, i.e. the consistent differentiation between us and them (Chouliaraki and Zaborowski 2017). This differentiation is often operated through racialised narratives that mobilise colonial reminiscences (Malkki 1996). The use of simplified categories of origin (Africans, Arabs), the explicit reference to religion to characterise Others (Muslims), the analysis of cultural differences as inferiority and as an inherent source of conflict, and the resort to metaphors that imply invasions or savagery are examples of this (Holmes and Castañeda 2016). As explained by Chouliaraki and Stolic (2017: 8),

Visualities of threat rely on the racialisation of refugees, where skin colour and clothing operate as signifiers of evil 'otherness' in 'our' midst - also reflected in animalistic references to 'swarms,' 'flocks,' or 'cockroaches', in the UK media.

Despite the breadth of the literature produced on this topic, less research has drawn attention to the mapping and analysis of gendered tropes present in the European and more specifically the English print media, hereby dismissing that security is gendered and gender constructions are in turn built on dynamics of in/security; and that gendered power relations and representations are always entangled with other structures of inequality and domination, such as racism. 


\section{Gender in securitisation moves}

Gender is understood here as a social construction and a system of meanings that creates social hierarchies based on the associations established with 'masculine' and 'feminine' traits and which relates either to persons or to objects (spaces, colours, food, institutions, professions, etc.). The specific contours and meanings of said associations change over time, depending on the context, as well as on the set of processes, discourses and structures that (re)produce and negotiate differentiations and hierarchies between people and things based on these categories. Once assigned, the power of gendered label is such

that the process by which the name was selected generally disappears and a series of normative associations, motives and characteristics are attached to the named subject. By naming, the subject becomes known in a manner which may permit certain forms of inquiry and engagement, while forbidding or excluding others (Bhatia 2005: 8).

Feminist security studies (Enloe 1990; Tickner 1992; Hansen 2000; Agathangelou and Ling 2004; Shepherd 2008; Sjoberg 2010; Wibben 2011) have been critical in arguing that gender along with other axis of power/subordination (Crenshaw 1991) is key to understanding international security theories, events, actors, policies, and implications. In the realm of security, more often than not these symbolic meanings attached to women and girls frequently involve associations with vulnerability, civility and innocence (Stiehm 1982; Elshtain 1987; Carpenter 2006; Ticktin 2011), and in the case of men and boys associations with violence, dominance and citizenship (Enloe 1993; Connell 1995), rendering particularly visible portraits of women as victims of violence, dispossession and displacement and agents for peace and of men as in/security actors (war combatants, terrorists, and protectors of racialised women) but also challenging ones.

Feminist security studies have also underlined the connections and tensions between the practices and representations of gender and violence and the consolidation of stereotypes regarding the margins/peripheries/South/Orient, portrayed as 'primitive,' 'savage' (Baaz and Stern 2009) and the height of patriarchy, where violence against women is commonplace (Agathangelou 2002). According to this imagination, the causes of violence are always local while the solutions are always external (Whitworth 2005; Shepherd 2008). The representations of violence in IR as explained through static constructions of the geography of women's abuse and protection are thus contested. For example, the discourses about 'women's rights and human rights' more often than not focus on the abuse of women outside the European and North American spaces:

In these discourses, the regions of the 'US,' 'Canada' and 'Western Europe' are territories of protections and rights; the geographical destinations of asylum are Northern states [...] Such discourses often elide the power relationships and structures of inequality that make rights claims possible through the regulation of national and international 'citizenship' (Agathangelou and Turcotte 2010: 44-45). 
During the last decade, several authors (Chowdhry and Nair 2002; Agathangelou and Ling 2004) participated in the deconstruction of women as a potentially collective, universal and homogenous subject, taking stock of thought developed decades before by postcolonial studies, and drawing attention in the IR and Peace Studies fields to the issues of representation and use of subaltern voices as a way to reinforce their marginalisation, subordination (Spivak 1988) and stereotyping - i.e. 'the production of the 'Third World Woman' as a singular monolithic subject' (Mohanty 1988: 61). Thus, the international production of violence is omitted through the occultation, normalisation and legitimation (namely through discourses that legitimise war) of 'structural hierarchies of desire, that is, the maintenance and enjoyment of privileges by the elites, even at the expense of the security of the majority of those living at the margins and peripheries (Agathangelou and Ling 2004: 519-520); or even through a great "variety of "colonization" practices that structure power relations globally, and resistance to those practices' (Chowdhry and Nair 2002: 12).

Hence, while research on gender, displacement and migration has underscored the importance of gender analysis beyond the focus on women (e.g., Ward 2002; Hajdukowski-Ahmed, Khanlou and Moussa 2013), literature on refugee flows and migration, with few exceptions (Jansen 2008; Hilhorst 2016), has remained concentrated on the important though insufficient topic of gendered violence endured by displaced people (Ghosh 2009). Similarly, research on 'regimes of care' (Ticktin 2011), which examines the actors involved in the humanitarian, legal assistance and protection of displaced populations (Carpenter 2006; Johnson 2011), has suggested that these regimes tend to focus predominantly on women's experiences of displacement, more often than not relying on gender essentialism that echoes the dictum that 'all the women are victims, all the men are in the militias' (Enloe 2004). Moreover, the equation of women and girls displaced with vulnerability has been used to mobilise support for humanitarian activity and refugee work (Johnson 2011). Recent studies (Krystalli, Hawkins and Wilson 2017) reiterate these findings, demonstrating that actors engaged in refugee assistance, states and humanitarian agencies alike, tend to equate vulnerability with 'womenandchildren' (Enloe 1990), thus failing to recognise the challenges that adult men and people outside the context of a heterosexual family unit face on the move, as well as neglecting them as priorities for protection and support, which, in turn, mirrors findings of broader research on masculinity and war (Sommers 2011; Myrtinnen, Khattab and Naujoks 2017) and peacetime (Connell 1995; Barker 2005).

Additionally, if in general men and masculinities tend to be understood a priori as potentially violent, this perception of violence tends to be particularly associated with threat and uncontrollable actions (as opposed to the use of violence as legitimate protection) when young racialised men are at stake. Usually, young men, and particularly those identified with a certain racial or cultural group or with the global South, are frequently represented in the media and in policy and political discourses as inherently problematic, associated with negative perceptions and threats to urban, national and international security. This representation is also anchored in several versions of the youth bulge theory, ${ }^{4}$ whose limitations have already been pertinently analysed. ${ }^{5}$ 
These gender assumptions, stereotypes and experiences are implicated not only in women's and men's in/security experiences and representations, but also in the constitution, causes and consequences of security events and policies. Identities play a key role in the rhetoric of 'creating' (in)security (Pears 2018): how we see and perceive ourselves defines our interests and, hence, what and who we treasure and intend to protect (Barnett 2014). As such, 'security stories tell us who to fear but also who [we believe] we are, and [what we define as] our place within the world' (Pears 2018: 126). As a successful securitising move 'rests [...] neither with the objects nor with the subjects but among the subjects' (Buzan et al. 1998: 31), it is usually built upon audiences' shared essentialised identities. As such, security is gendered, and gender constructions intersecting with other identity markers such as race and age are built on dynamics of in/security. Specifically, ideas on masculinities and femininities influence perceptions of who is vulnerable and in need of assistance and who is a threat, shaping scholarship, media reports, policy, and daily lives.

\section{Methodology}

Even though social media played a relevant role in intra- and extra-European information exchanges, especially by the refugees themselves, by helping them to maintain contact with their countries of origin (Gillespie et al. 2016), the news media were particularly important in the information and updating of both European audiences and political elites and decision makers, especially the fast-paced succession of events in the entry and transit points of these fluxes (i.e., maritime rescue operations, refugee centres and debates within national and European formal policy spheres) after April 2015 (Georgiou and Zaborowski 2017: 3).

This article is not intended to be exhaustive nor detailed in its analysis, but rather to signal some of the gendered and racialised tropes that appear in these media narratives, following three specific and highly mediatised events: the shipwrecks in the Mediterranean in April 2015; the terrorist attacks on French soil in 2015; and the sexual assaults in 2015/2016 on New Year's Eve in Cologne. Therefore, it does not seek to draw and conduct a systematic and comparative analysis of regional and temporal trends in the journalistic coverage of the so-called 'Europe refugee crisis.' Specifically, it intends to explore whether the overall European media coverage of events labelled as the 'European refugee crisis' has in fact contributed to informing the various actors of what was actually happening, representing refugees and other distinct voices in a fair and balanced way, or whether, on the contrary, it has helped to consolidate racialised and gendered readings of security.

Given the exploratory character of this article, we chose to focus on the British news media, since the United Kingdom has been one of the main voices in the migration and asylum debate within the EU, despite its 'opt-out' from EU immigration and asylum issues, ${ }^{6}$ and it is generally a destination country for asylum seekers and migrants alike. Nonetheless, it would be interesting to analyse media narratives from countries such as Greece, Italy, Hungary and Poland, which constitute the main entry and transit points of these population flows. We chose to analyse the media coverage of reference newspapers 
(R), namely The Guardian and the Telegraph, because of their proximity to and consumption by political elites and its reach and credibility among news audiences, as well as popular newspapers (T), in this case the Daily Mirror and Daily Mail, as a result of their broad universe of readers.

In fact, while the news coverage of the so-called 'refugee crisis' is diverse within the European context, the coverage in the United Kingdom emerges as one of the most polarised and aligned along ideological lines, with left-wing newspapers, such as the reference newspaper (R) The Guardian and the tabloid (T) Daily Mirror predominantly focusing on the humanitarian effects of the 'crisis' and its securitisation, and the newspapers associated with the conservatives, especially the Daily Mail (T) and the Telegraph (R) concentrating on issues such as confrontations in Calais, the humanitarian problems generated by the arrival and movement of these people across Europe, namely, highlighting the role of smugglers who profit from the crossings and the problems that these population fluxes represent to the European/English culture, to the national health and welfare systems and to national/European security (Berry, Garcia-Blanco and Moore 2015; Georgiou and Zaborowski 2017). The news coverage that followed the death of more than a thousand people in the Mediterranean in April 2015 is an example of this, in that newspapers such as The Guardian criticised the European approach to the crisis and the use of military force to put a halt to the action of people smugglers, with reports and opinion pieces by reporters and NGO professionals defending the creation of more reception centres aimed at refugees and the opening of legal migration routes, whereas newspapers such as the Telegraph and the Daily Mail supported military solutions and criticised both the EU plans to create a quota system for hosting refugees and UN action in several editorials and opinion pieces.

\section{The 'South in the North' and media-gendered tropes}

\section{Vulnerable 'women and children'}

Even though women and children were not the main focus of the media accounts on the 'European refugee crisis' (Allsopp 2015), women and children are the asylum seekers most frequently portrayed as the visible victims of war and thus the most credible, unsuspicious, non-threatening refugees. Articles on women's and children's vulnerability and exposure to violence in refugee and migrant detention camps in Calais, France, such as "The men have knives and drink and fight. We are scared of being raped": What life is REALLY like for migrant women and children trapped in the Calais "Jungle" camp' (Daily Mail 2015f) and 'Women and children arriving at Calais's migrant camps "need greater protection" (The Guardian 2015e), confirm the association of women to children and the tendency to represent them both as in danger and without agency, namely through favouring third person reports about their situation (typically accounts from local police and NGO staffers), instead of their own voices.

The recurring resort to UNHCR statistics (2016) and those of other UN agencies, such as UNESCO (2016), by different newspapers is revealing of the diverse gender analy- 
sis that can be made about these data. Some newspapers, such as The Guardian, in specific moments maintain that children represent $51 \%$ of all refugees worldwide and that $75 \%$ of all refugees are women and children, reinforcing, at first sight, the narrative that places women and children as the primary victims and refugees; however, other newspapers, namely the Daily Mail and the Telegraph, state that $75 \%$ of all refugees are children and men. Although both are factually correct, as Davis (2016: 49) explains,

Just over 50 percent of the refugees are children, and thus slightly less than 50 percent are adults. The statistics also show, with variation among host countries, that about half the adults are women and half are men; thus indeed, some 75 percent of the refugees are women and children. But equally, 75 percent of the refugees are men and children. Yet that statistic is never cited as significant, nor is it used to stir empathy for the refugees or create policy and programming.

On the contrary. In fact, there appears to exist some form of symmetry in the way this statistic is used, either to contest or raise suspicion about the authenticity of refugees.

These tropes are not unprecedented and coincide with some of the conventional gendered accounts about armed conflict and humanitarian emergencies and other crisis or securitisation scenarios, such as in the cases of migration control regimes, and are present in media analysis, political discourse, ${ }^{7}$ scholarship and activist accounts alike. These tropes resonate with what Elshtain (1987) examined in her historical and personal analysis of the interactions between gender and war in the West in terms of gender expectations that associate masculinity with violence and war making and femininity with peace. According to the dichotomous narrative that juxtaposes 'just warriors' and 'beautiful souls' (Elshtain 1987), ${ }^{8}$ the first sacrifice themselves in order to protect (their) women and children and rescue the enemy's women and children, which Cynthia Enloe (1990; 1993) designated 'womenandchildren', since they constitute simultaneously the war's objects, prizes and just motives. This agglutinated expression ${ }^{9}$ aims to draw attention firstly to the naturalised connection between women and children, secondly to the common presumption of their being innocent victims upon whom is inflicted violence, and thirdly to their role as innate, non-strategic, peace actors. This rigid role division promotes a romanticised account of war, effectively rendering politics and war as masculinised realms and justifying and legitimising war as a solution to ensure the protection of the most vulnerable segments of the population (Enloe 1990, 1993).

Scholars such as Adam Jones (2000) drew attention to the repercussions of marginalising the recognition and politicisation of men's suffering in situations of armed conflict as a result of the enduring association of women and children to civilians and the insistent reference to these as 'the main victims of armed conflict' (UNSCR 2000; Tickner 2001: 2). In the same vein, Charli Carpenter (2006) examined the way in which humanitarian actors, such as UN agencies and activist organisations, interpret the principle of civilian immunity as referring first and foremost to women, children and the elderly, leaving civilian men and boys unprotected. In fact, the homogenising category of 'womenandchildren' exists in opposition to youth (read as masculine) and men. 
This portrayal of women and children as legitimate and deserving refugees is also racialised, reinforcing stereotypes about non-western men and women, given their frequent graphic representation together, especially with the latter veiled or given their description by third parties as vulnerable or suffering, thus resonating with the trope 'white men saving brown women from brown men ${ }^{10}$ (Spivak 1988). This understanding ties with Said's conceptualisation of Orientalism, that is, a discursive practice produced and reproduced by western cultures about other societies, which works to distort and exaggerate differences between 'the Orient' (i.e., the Arab and Muslim world) and 'the Occident' (i.e., the western world). This practice generally involves a stereotyping portrayal of non-western persons as particularly bad or particularly beautiful. In the case of Arab and Islamic cultures, it tends to portray them as backward and contrary to women's rights (Said 2003: xiv).

According to this representation, non-western women and children, especially those from the Middle East, such as Syrian refugees, flee from the war between 'brown men' and from cultural impositions, such as the veil, which symbolise the antithesis to the western world and its values. The recurrence and centrality of images of Muslim women using a veil in the graphic representations that accompany the news stories, and which allude to their oppression at various levels at the hands of 'brown men' especially in religious terms, reiterate this representation. This choice and frequency of use also alludes to a specific notion of Muslim religion as antithetical to modernity, i.e., rigid, rooted in tradition, and resistant to change, especially with regard to women's rights. In the face of this, western culture and secular European values are often presented as synonymous with gender equality and also as a response to the end of this type of oppression (Ferris 2011: 623). This process of constructing the otherness of oppressed Muslim women was reinforced by the publication of news articles about the sexual assaults perpetrated in Cologne and other German cities during New Year's Eve in 2015/2016. These reports consolidated Muslim women's legitimacy as refugees and as deserving - 'in need of saving' - of being hosted in Europe, while further crystallising gendered and racialised representations of Muslim refugee men as dangerous and oppressive, which underpin many media narratives that highlight the need to intensify border control in Europe as well as some governmental initiatives, such as the one proposed but not implemented by Justin Trudeau of Canada, and which consisted of an expedited mechanism designed to resettle women and children refugees as well as whole families (The Guardian 2015b).

\section{Threatening men: race and young age in the spotlight}

In the media representation of refugee men, three particular tropes stand out: the young men or youth (coded male) who are: (1) either economic migrants in disguise or someone lured by the benefits of the European welfare system; (2) 'pre-emptive suspects' (Stephen 2017), 'strong young men' (Time 2015), according to Trump just before his inauguration as the $45^{\text {th }}$ president of the USA, 'fit young men' (Daily Mail 2015b) in the words of the then British Foreign Minister Philip Hammond, and 'like an army' (Daily Mail 2015f), for Viktor Orbán, the Hungarian Prime Minister, all of whom are potential criminals or vio- 
lent perpetrators, infiltrated terrorists or rapists; or, on the other hand, (3) cowards, who have not lived up to their gendered expectations of waging war, as pointed out by Elshtain (1987) in the chapter of Women and War called 'Men: The Militant Many/The Pacific Few.'

The representation of young men, 'battle or military aged men,' whose ages range between 16 and 50, is associated, on the one hand, with illegitimate or bogus refugees, economic migrants disguised as refugees deluded by the possibility of benefits and protection, who take advantage of the height of the refugee crisis to migrate to Europe. News articles highlighting the annual cost of refugees in the United Kingdom, such as 'Each Syrian refugee to cost Britain $£ 24,000$ a year' (Telegraph 2015b) and 'Taxpayers to fork out $£ 24,000$ per year for each Syrian refugee' (Daily Mail 2015e), constitute examples of this trope.

But the disbelief and distrust concerning these refugees has been accentuated by gendered references to their age, physical ability and apparent economic possibilities, in articles such as 'Many refugees walking across Europe are fit young men looking for work, says Philip Hammond [then British Foreign Minister]' (Daily Mail 2015b) and 'Migrant crisis: Are these happy young men really timid souls fleeing war and persecution?' (Express 2015), and complemented by news pieces in some tabloids as 'smartphone wielding refugees' (Daily Mail 2015d).

In this case, it is important to note the work of Rochelle Davis, Abbie Taylor and Emma Murphy (2014) on Syrian men who escaped from compulsory military service in the country and from the forced recruitment by non-state forces. Since 2012, UNHCR data show that Syrian men are not staying in the country to fight, but they are running away in numbers similar to women in the same age groups: of the $4.8 \mathrm{~m}$ registered Syrian refugees, $50.3 \%$ are men and $49.7 \%$ women (21.6\% are men between 18 and 59 and $22.5 \%$ women of the same age group) (Davis, Taylor and Murphy 2014).

References to youth and physical ability coupled with the use of smartphones were made in the context of the terrorist attacks in Paris in November 2015, after a smartphone was recovered and a Syrian passport was allegedly found near one of the dead terrorists. Australian Prime Minister Malcolm Turnbull referred to smartphones as 'terrorist essentials' ( $A B C$ 2015), thus reinforcing the link between terrorism and refugees and between masculinity and militarism (through the use of photographs showing young refugee men taking selfies). In turn, the Daily Mirror (2015) and The Guardian covered the issue of cell phone use from another angle, explaining its role in maintaining contact with their country of origin.

As the securitisation framing of the crisis progressed, highlighting at first the confrontations at the Hungarian border and the conflicts in Calais, and at a later stage in the aftermath of the Paris terrorist attacks and the New Year's Eve sexual assaults in Cologne, the representation of refugees as criminals and potential terrorists gained space in the media, with articles featuring the confrontations between refugees and the police in the refugee camps, as shown in the news pieces 'And then came the rains: Thousands of migrants battle with riot police in Macedonian quagmire after storms batter eastern Europe' (Daily Mail 2015a), 'Open the border - we're going to the UK! Chanting mob of 200 storm tunnel entrance and pledge they won't be stopped' (Daily Mail 2015c), and "Religious tensions" spark gunfight in French migrant camp' (Telegraph 2015c). 
At a later stage, the references to the refugees as threats to national/European security progressively took centre stage in media reports (i.e., the accounts about possible infiltrated terrorists, such as the photograph that circulated featuring an alleged ISIS commander who was trying to enter Europe), including declarations from European and US politicians that referred to refugees as potentially 'infiltrated by Muslim extremists' (Telegraph 2015a) or 'ISIS “trojan horse[s]"' (Daily Mail 2015g). Meanwhile the coverage of the 2015/2016 New Year's Eve sexual assaults in Cologne inaugurated the depiction of young male refugees as threats to the West's culture and way of life, by portraying them as disrespecting women's rights and the culture of secularism in Europe.

After a notorious delay in the reporting of said events, which raised suspicion (see Luyken (2016)), the news coverage by both reference and tabloid newspapers depicted male refugees, mostly young, as 'Arab looking,' dangerous, violent and particularly misogynist. The incident was widely reported as being organised and carried out, according to the Cologne police chief, by people who 'from appearance were largely from the North African or Arab world' (Telegraph 2016c). As a result, headlines focused on these early descriptions to link to the migrants, for example in 'Groped between the legs and a firework thrown into a hoodie: Brave female victims reveal the horrifying details after attacks by sex mob of 2,000 "North African and Arab" men in Cologne' (Daily Mail 2016a), and in 'Europe in crisis over sex attacks by migrants amid calls for emergency EU meeting' (Telegraph 2016b). The moral panic created around this incident fed into, and was informed by, discourses of othering, with some media reports depicting Arab or Muslim male refugees as a particular threat to women's rights, namely by subscribing to a different culture perceived as inherently sexist and violent towards women ('Rapefugees') (Daily Mirror 2016), thus mobilising the representations of the Orientalist discourse toolbox (Telegraph 2016a and Daily Mail 2016b).

While we acknowledge the actual violence of the attacks and support the need for media coverage, police investigation and the victims' rights to justice, we also defend the need for critically questioning the way in which the characteristics of those perpetrating the assaults came to be portrayed as a defining feature of all migrants and asylum seekers from the global South, prompting attacks on immigrants and refugees in Germany in the following days.

\section{Counter-narratives on the refugees flows}

Despite these hegemonic gendered and racialised representations of refugees as 'dangerous young men', especially salient within the securitisation media frame, and as 'womenandchildren, particularly present in humanitarian-based media narratives, there were noticeable alternative gendered and racialised representations that are worth exploring.

One important counter-representation is the one that depicts women refugees as agents. The piece 'Fattemah's choice: Stay in a warzone or risk losing her baby on journey to Europe' (The Guardian 2015c) focuses on a woman's decision-making process to flee. In other articles on the demonstrations of women refugees in Calais, the agency of women 
in denouncing violence in refugee camps as well as poor health and hygiene conditions is highlighted (Daily Mail 2015f).

Another important alternative representation of refugees is the one that presents male refugees as fathers and caregivers. The portrayal of Laith Majid and his family's arrival in Greece, captured in the iconic photograph of him hugging his son and daughter after their safe arrival on the Greek Island of Kos, initially published by The New York Times, together with the pieces on Aylan Kurdi's death and his burial in Kobane, where the anguish and mourning of his father took centre stage (Allsopp 2015; The Guardian 2015a; Telegraph 2016d), drew attention to the vulnerability of men amid war and when fleeing war. Together these pieces depict non-violent masculinities and contradict and/or counterbalance the most common representations of men as involved in violent clashes along the Hungarian border, in the Calais camp or in the sexual assaults of Cologne, thus complementing the stories more often reported by the media, NGO and international organisations and a segment of the research dedicated to women and children victims of war and displacement. These counter-hegemonic representations defied the invisibility to which men are relegated in accounts of war and humanitarian crisis and made male refugees visible as caring actors, an even less common trope in media reports. Nonetheless, men's experiences of vulnerability in war scenarios, either as civilians or as combatants, remain the object of little attention in the media, especially if compared with women's victimisation and the hypervisibility of men's violent experiences.

Moreover, news pieces such as 'Labour MP Jesse Phillips defends comments comparing Cologne sex attacks to a night out in Birmingham' (Daily Mirror 2016b) sought to challenge the link between refugee's and/or migrant men's and women's human rights threats by deracialising the issue of violence against women. By highlighting the sexist nature of advances that women endure in the UK, referencing the case of Birmingham's nightlife, Jesse Philips suggests the widespread, global and transcultural dimension of violence against women and gender-based violence.

Finally, it is worth mentioning that several news articles provided contradictory or ambiguous elements concerning the representation of refugees. Many news pieces in tabloid newspapers, namely in the Daily Mirror, particularly those covering the 2015/2016 New Year's Eve Cologne attacks and the protests that followed, reproduce the anti-refugee sentiment and rhetoric, while putting forward alternative narrative elements, such as photographs of the female demonstrators in Germany that adopt both antisexist and antiracist positions (Daily Mirror 2016c).

\section{Conclusions}

This article has shown that the dichotomy between credibility and non-credibility enacted by media reports about the so-called 'European refugee crisis' was made explicit not only by the choice and repeated use of the labels such as 'migrants' or 'immigrants' to designate asylum seekers/refugees (with the Daily Mirror, Daily Mail and Telegraph favouring the use of 'migrants' and to a lesser extent 'illegals' and 'aliens,' in detriment to 'refugees') 
(Berry, Garcia-Blanco and Moore 2015: 35-36), but also by the resort to gendered, aged and racialised accounts of said populations.

Focusing on the media narratives generated during the peak of the crisis, this analysis demonstrated that gendered and racialised media representations of refugees, including those with a humanitarian focus, such as the ones which narrowly associate women and children as a whole with civilians, innocent victims, or the most vulnerable populations in situations of war, and designate men, namely young men, as dangerous, even when they are actually fleeing war, contributed to the creation of a hierarchy among asylum seekers, legitimising some in detriment of others.

In fact, the media's predominant focus on young, healthy-looking men on the move, a trend that was consolidated in the aftermath of the Paris terrorist attacks of November 2015 and of Cologne's 2015/2016 New Year's Eve sexual assault cases, further consolidated the securitisation of the refugee crisis that was already under way and demonstrated how the media contributes to the creation of 'moral economies' (Ticktin 2011: 98) by more often than not mirroring and reinforcing existing gendered stereotypes and hierarchies. The frequent association of men and especially young men with threat and danger and that of women and girls with innocence and vulnerability, alongside heterosexual notions of family (comprised of a female and a male parent and children), not only constitute narrow representations of refugee populations, limiting our ability to consider their experiences and lives in a more complex manner and contributing to dissemination of fear and antiimmigration-based sentiments and policies across Europe, but also can in fact lead to the marginalisation of the needs of the refugees seeking assistance or protection. Nevertheless, in spite of the dominant securitisation frame put forward by the British media when portraying refugee flows, more nuanced media representations have also emerged. These accounts explore the complexity of refugees' experiences by explicitly deconstructing gendered and racialised hegemonic media representations and offering alternative and more comprehensive views of the 'South in the North', going beyond the traditional hierarchies of suffering and care.

\section{Notes}

1. This and other expressions such as 'the European refugee crisis' are mistaken and misleading, since they suggest that this is a crisis for Europe rather than a crisis for refugees. As shown by UNHCR data, Europe is the continent with a lower percentage of refugees in its midst (6\%), falling far behind the American continent (12\%), Asia and Pacific (14\%), Middle East and Northern Africa (39\%) and the remaining African continent (29\%). Syrian refugees, for example, are mostly hosted in neighbouring countries, namely in Turkey, Lebanon, Jordan and Iraq. Despite the fact that around one million refugees reached Europe by sea, this number represents only $0.3 \%$ of the continent's total population. For more information, see UNHCR (n.d.).

2. In terms of its dynamic structure, securitisation integrates three different elements: a referent object, securitisation actors and functional actors (Buzan et al. 1998: 36).

3. i) Visibility as biological life, associated with monitorial action; ii) visibility as empathy associated with charitable action; iii) visibility as threat, associated with state security; iv) visibility as hospitality, associated with political activism; and v) visibility as self-reflexivity, associated with a post-humanitarian engagement with people like 'us' (Chouliaraki and Stolic 2017). 
4. It consists of the idea that a high percentage of young men - considered the main perpetrators of violence in the demographic composition of a society, namely in urban areas, leads to a greater likelihood of violent phenomena, including 'armed conflicts, terrorism and riots' (Urdal 2006: 608).

5. Marc Sommers summarises some of the flaws of this theory: the fact that some studies find a correlation between the two variables does not mean that is a relation of causality between them; it ignores that 'most young men' in these contexts 'have never been involved in violent incidents' (Barker and Ricardo 2005: 181); the studies are not based in any qualitative work and do not investigate the experiences and perceptions of young men in these countries (generally associated with the global South and with Africa in particular); it ignores the role of other actors in the organisation of violence (Sommers 2011).

6. For example, the UK has insisted that refugees claim asylum in the first safe country they come to, which is now practice within the EU, and the May government has been a vocal supporter of the recent EU-Turkey agreement to reduce the flow of refugees across the Aegean, while it has provided Italy and Greece with significant numbers of asylum staff to help process asylum claims and facilitate the return of those who are denied such status. As a recent newspaper article put it: 'When it comes to refugee policy, Britain may not have joined Europe but Europe is rapidly joining Britain' (Travis 2017).

7. For example, the rhetoric of 'women's rights', using the image of women and children and innocent victims of the Taliban regime, was used by G. W. Bush and Laura Bush to gather support for the invasion of Afghanistan in 2001 against the will of Afghan women's organisations (Shepherd 2006).

8. Elshtain criticises the manicheism of the western dualistic representations of men-women. The idea of 'beautiful soul' is used to designate women in general as innocent and external to the violent course of history, whereas men are often portrayed in western culture as brave warriors, who go to war not to kill but to die for a cause.

9. The expression 'womenandchildren' was coined by Enloe in the context of the first Gulf War, when Iraq invaded Kuwait. In her words, 'In the torrents of media images that accompany an international crisis, women are typically made visible as symbols, victims or dependents. "Womenandchildren" rolls easily off network tongues, because in network minds women are family members rather than independent actors, presumed to be almost childlike in their innocence about international realpolitik' (Enloe 1993: 166).

10. The expression was first used in the context of interpreting the British attempt to save 'brown women from brown men' in India at the time of English colonisation, but it was also used later on by Spivak in the context of the war on terror. In her view, and without denying that women are in fact oppressed, the politics of rescuing Muslim women are guided by liberal ideas of individualism and choice and a neo-Orientalist take on the world, often present in political discourses of 'white men's burden' voiced by western great powers, such as the USA, as well as in seemingly benevolent actions and policies, including ones led by western white feminist movements, which are in fact violent and may constitute a pretext to legitimise violent neo-colonial interventions aimed at 'freeing' certain groups and parts of the world, including through military action.

\section{References}

$A B C$ [online]. 2015. "Islamic State: Malcom Turnbull declares terrorist group "weak" in first national security statements as PM.' 24 November. At http://www.abc.net.au/news/2015-11-24/malcolmturnbull-delivers-national-security-statement/6968858 [Accessed on 2 January 2018].

Agathangelou, Anna M. 2002. “Sexing” globalization in international relations: Migrant sex and domestic workers in Cyprus, Greece, and Turkey' In Geeta Chowdhry and Sheila Nair (eds), Power, Postcolonialism and International Relations. Reading race, gender and class. London/New York: Routledge, pp. 142-169.

Agathangelou, Anna M and Heather M Turcotte. 2010. 'Postcolonial theories and challenges to 'First World-ism.” In Laura Shepherd (ed), Gender Matters in Global Politics: A Feminist Introduction to International Relations. London: Routledge, pp. 36-48. 
Agathangelou, Anna M and L H M Ling. 2004. 'Power, borders, security, wealth: Lessons of violence and desire from September 11.' International Studies Quarterly 48 (3): 517-538.

Allsopp, Jennifer. 2015. 'Refugee crisis: Demilitarising masculinities.' Open Democracy, 17 September. At https://www.opendemocracy.net/5050/jennifer-allsopp/refugee-crisis-demilitarising-masculinities [Accessed on 2 January 2018].

Baaz Eriksson, Maria and Maria Stern. 2009. 'Why do soldiers rape? Masculinity, violence, and sexuality in the armed forces in the Congo (DRC).' International Studies Quarterly 53 (2): 495-518.

Barker, Gary and Christine Ricardo. 2005. 'Young men and the construction of masculinity in SubSaharan Africa: Implications for HIV/AIDS, conflict, and violence.' Social Development Papers: Conflict Prevention and Reconstruction Paper No. 26. Washington: The World Bank. At http://documents.worldbank.org/curated/pt/481401468101357773/pdf/327120rev0PAPER0AFR0young0men 0WP26.pdf [Accessed on 8 January 2018].

Barker, Gary. 2005. Dying to Be Men: Youth, Masculinity and Social Exclusion. London: Routledge.

Barnett, Michael. 2014. 'Social Constructivism.' In John Baylis and Steve Smith (eds), The Globalization of World Politics. Oxford: Oxford University Press, pp. 155-168.

Barrinha, André. 2011. 'The political importance of labelling: Terrorism and Turkey's discourse on the PKK.' Critical Studies on Terrorism 4 (2): 163-180.

Berry, Mike, Inaki Garcia-Blanco and Kerry Moore. 2015. 'Press Coverage of the Refugee and Migrant Crisis in the EU: A Content Analysis of Five European Countries.' Report prepared for the United Nations High Commission for Refugees, Cardiff School of Journalism, Media and Cultural Studies. At http://www.unhcr.org/56bb369c9.pdf [Accessed on 8 January 2018].

Bhatia, Michael V. 2005. 'Fighting words: Naming terrorists, bandits, rebels and other violent actors.' Third World Quarterly 26 (1): 5-22.

Buzan, Barry, Ole Wæver and Jaap de Wilde. 1998. Security: A New Framework for Analysis. Boulder: Lynne Rienner.

Carpenter, Charlie. 2006. 'Innocent Women and Children: Gender, Norms and the Protection of Civilians.' London: Ashgate.

Chouliaraki, Lilie and Rafal Zaborowski. 2017. 'Voice and community in the 2015 refugee crisis: A content analysis of news coverage in eight European countries.' International Communication $\mathrm{Ga}$ zette 79 (6-7): 613-635. At http://eprints.lse.ac.uk/84707/ [Accessed on 20 January 2018].

Chouliaraki, Lilie and Tijana Stolic. 2017. 'Rethinking media responsibility in the refugee "crisis": A visual typology of European News.' Media, Culture and Society 39 (8): 1162-1177. At http://eprints. lse.ac.uk/84874/ [Accessed on 21 January 2018].

Chowdhry, Geeta and Sheila Nair. 2002. 'Introduction: Power in a postcolonial world: Race, gender, and class in international relations.' In Geeta Chowdhry and Sheila Nair (eds), Power, Postcolonialism and International Relations. Reading race, gender and class. London/New York: Routledge, pp. $1-32$.

Colombo, Monica. 2017. 'The representation of the "European refugee crisis" in Italy: Domopolitics, securitization, and humanitarian communication in political and media discourses.' Journal of Immigrant \& Refugee Studies 16 (1-2): 161-178.

Connell, Raewyn. 1995. Masculinities. Berkeley: University of California Press. 
Crenshaw, Kimberley. 1991. 'Mapping the margins: Intersectionality, identity politics, and violence against women of color' Stanford Law Review 43 (6): 1241-1299.

Daily Mail [online]. 2015a. 'And then came the rains: Thousands of migrants battle with riot police in Macedonian quagmire after storms batter eastern Europe.' 10 September. At http://www.dailymail. co.uk/news/article-3228985/Slipping-cover-darkness-Migrants-continue-crawl-Hungary-s-flimsyborder-fence-warns-42-000-refugees-enter-country-ten-days.html [Accessed on 15 January 2018].

2015b. 'Many refugees walking across Europe are "fit young men looking for work", says Philip Hammond.' 20 October. At http://www.dailymail.co.uk/news/article-3281083/Many-refugees-walking-Europe-fit-young-men-looking-work-says-Philip-Hammond.html [Accessed on 15 January 2018].

2015c. 'Open the border - we're going to the UK! Chanting mob of 200 storm tunnel entrance and pledge they won't be stopped.' 2 August. At http://www.dailymail.co.uk/news/article-3183314/ Open-border-going-UK-Chanting-mob-200-storm-tunnel-entrance-pledge-won-t-stopped.html [Accessed on 15 January 2018].

2015d. 'Smartphones are the secret weapon fuelling the great migrant invasion.' 28 September. At http://www.dailymail.co.uk/debate/article-3251475/DOMINIC-LAWSON-Smartphonessecret-weapon-fuelling-great-migrant-invasion.html [Accessed on 15 January 2018].

2015e. 'Taxpayers to fork out $£ 24,000$ per year for each Syrian refugee.' 20 October. At http:// www.dailystar.co.uk/news/latest-news/471042/Syria-refugee-crisis-David-Cameron-Home-Office [Accessed on 15 January 2018].

2015f. “The men have knives and drink and fight. We are scared of being raped": What life is REALLY like for migrant women and children trapped in the Calais "Jungle" camp.. 25 September. At http://www.dailymail.co.uk/femail/article-3247705/What-life-REALLY-like-migrant-womenchildren-trapped-Calais-Jungle-camp.html\#ixzz4dSwnqdUO [Accessed on 15 January 2018].

2015g. "Trump warns Syrian refugees could be ISIS “Trojan horse" in the US and blasts Merkel for "insane" plan to accept more than one million migrants to Germany. 17 October. At https://www.dailymail.co.uk/news/article-3268474/Trump-warns-Syrian-refugees-ISIS-Trojanhorse-blasts-Merkel-insane-plan-accept-1-million-migrants-Germany.html [Accessed on 15 January 2018].

2016a. 'Groped between the legs and a firework thrown into a hoodie: Brave female victims reveal the horrifying details after attacks by sex mob of 2,000 "North African and Arab" men in Cologne.' 6 January. At http://www.dailymail.co.uk/news/article-3386673/Women-Cologne-lockdown-council-admits-no-longer-safe-wake-African-Arab-mob-s-rapes-declares-upcoming-carnival-no-area-females.html [Accessed on 15 January 2018].

2016b. 'The Arabic gang-rape "Taharrush" phenomenon which sees women surrounded by groups of men in crowds and sexually assaulted... and has now spread to Europe.' 12 January. At http:// www.dailymail.co.uk/news/article-3395390/The-Arabic-gang-rape-Taharrush-phenomenon-seeswomen-surrounded-groups-men-crowds-sexually-assaulted-spread-Europe.html\#ixzz56vjLxYD3 [Accessed on 15 January 2018].

Daily Mirror [online]. 2015. 'Refugees heart breaking mobile snaps reveal what migrants lose in fleeing war-torn homelands.' 19 November. At http://www.mirror.co.uk/news/world-news/refugeesheartbreaking-mobile-phone-snaps-6860831 [Accessed on 15 January 2018]. 
.2016a. "Rape refugees not welcome”: Protesters in Cologne force Merkel response following mass New Year's Eve sex attacks.' 12 January. At https://www.mirror.co.uk/news/world-news/raperefugees-not-welcome-protesters-7162503 [Accessed on 15 January 2018].

. 2016b. 'Labour MP Jess Phillips defends comments comparing Cologne sex attacks to a night out in Birmingham.' 29 January. At https://www.mirror.co.uk/news/uk-news/labour-mp-jessphillips-defends-7268196 [Accessed on 2 July 2018].

2016c. 'Cologne sex attacks: Leaked police report reveals 1,000-strong mob taunted cops after assaulting more than 100 women.' 7 January. At https://www.mirror.co.uk/news/world-news/ cologne-sex-attacks-leaked-police-7137471 [Accessed on 2 July 2018].

Davis, Rochelle, Abbie Taylor and Emma Murphy. 2014. 'Gender, conscription and protection, and the war in Syria.' Forced Migration Review 47: 35-38.

Davis, Rochelle. 2016. 'Gendered vulnerability and forced conscription in the war in Syria.' Middle East Centre Blog, 27 September. At http://eprints.lse.ac.uk/67728/2/ForcedDisplacement. pdf $\#$ page $=49$ [Accessed on 15 January 2018].

Elshtain, Jean B. 1987. Women and War. New York: Basic Books.

Empinotti, Maria Lisboa. 2017. 'Discriminação no discurso: análise da representação de refugiados no Público através da gramática visual de Kress e Van Leeuwen.' Media \& Jornalismo 17 (31): 95-116.

Enloe, Cynthia. 1990. 'Womenandchildren: Making feminist sense of the Persian Gulf crisis.' Village Voice, 25 September.

1993. The Morning After: Sexual Politics at the End of the Cold War. Berkeley: University of California Press.

2004. The Curious Feminist. Searching for Women in a New Age of Empire. Berkeley: University of California Press, pp. 99-118.

Express [online]. 2015. 'Migrant crisis: Are these happy young men really timid souls fleeing war and persecution?' 20 September. At http://www.express.co.uk/news/world/603511/Migrant-crisisrefugees-take-selfie-photo-Greek-boat-Lesbos-Syria-war [Accessed on 21 January 2018].

Ferris, Elizabeth. 2011. 'Faith and humanitarism: It's complicated.' Journal of Refugee Studies 24 (3): 606-627.

Fleras, Augie and Jean Lock Kunz. 2001. Media and Minorities: Representing Diversity in a Multicultural Canada. Toronto: Thompson Educational Publishing Inc.

Georgiou, Myria and Rafal Zaborowski. 2017. 'Media Coverage of the "Refugee Crisis": A CrossEuropean Perspective.' Council of Europe report DG1(2017)03. Strasbourg: Council of Europe. At https://rm.coe.int/CoERMPublicCommonSearchServices/DisplayDCTMContent?documentId=09 000016806d8c9e [Accessed on 15 January 2018].

Ghosh, Jayati. 2009. 'Migration and Gender Empowerment: Recent Trends and Emerging Issues.' Human Development Research Paper 2009/04. April. At http://hdr.undp.org/sites/default/ les/ hdrp_2009_04.pdf [Accessed on 18 January 2018].

Gillespie, Marie, Lawrence Ampofo, Margaret Cheesman, Becky Faith, Evgenia Illiadou, Ali Issa, Souad Osseiran and Dimitris Skleparis. 2016. 'Mapping Refugee Media Journeys Smartphones and Social Media Networks.' The Open University and France Médias Monde Research Report At http:// www.open.ac.uk/ccig/sites/www.open.ac.uk.ccig/files/Mapping\%20Refugee\%20Media\%20Journeys\%2016\%20May\%20FIN\%20MG_0.pdf [Accessed on 15 January 2018]. 
Giuliani, Gaia. 2016. 'Monstrosity, abjection and Europe in the War on Terror.' Capitalism Nature Socialism 27 (4): 96-114.

Hajdukowski-Ahmed, Nazilla Khanlou and Helene Moussa (eds). 2013. Not Born a Refugee Woman: Contesting Identities, Rethinking Practices. New York: Berghahn Books.

Hall, Stuart. 1997. 'The work of representation.' In Stuart Hall (ed), Representation: Cultural Representations and Signifying Practices. London: Sage Publications, pp. 13-74.

Hansen, Lene. 2000. 'The Little Mermaid's silent security. Dilemma and the absence of gender in the Copenhagen School.' Millennium: Journal of International Studies 29 (2): 285-306.

Helms, Elissa. 2015. 'Men at the borders: Gender, victimhood, and war in Europe's refugee crisis.' FocaalBlog, 22 December. At www.focaalblog.com/2015/12/22/elissa-helms-men-at-the-bordersgender-victimhood-and-war-in-europes-refugee-crisis [Accessed on 15 January 2018].

Hilhorst, Thea. 2016. 'The other half of gender: Are humanitarians blind to the vulnerabilities of male refugees?’ At https://www.oneworld.nl/overig/other-half-gender-are-humanitarians-blindmale-suffering/ [Accessed on 15 January 2018].

Holmes, Seth M and Heide Castañeda. 2016. 'Representing the "European refugee crisis" in Germany and beyond: Deservingness and difference, life and death.' American Ethnologist 43 (1): 12-24.

Hoyer, Ariana. 2016. 'Spanish news framing of the Syrian refugee crisis.' WWU Honors Program Senior Projects 26. At http://cedar.wwu.edu/wwu_honors/26 [Accessed on 25 January 2018].

Jansen, Stef. 2008. 'Misplaced masculinities: Status loss and the location of gendered subjectivities amongst "non-transnational” Bosnian refugees.' Anthropological Theory 8 (2): 181-200.

Johnson, Heather L. 2011. 'Click to donate: Visual images, constructing victims and imagining the female refugee.' Third World Quarterly 32 (6): 1015-1037.

Jones, Adam. 2000. 'Gendercide and genocide.' Journal of Genocide Research 2 (2): 185-211.

KhosraviNik, Majid. 2010. 'The representation of refugees, asylum seekers and immigrants in British newspapers: A critical discourse analysis.' Journal of Language and Politics 9 (1): 1-28.

Krystalli, Roxanne, Allyson Hawkins and Kim Wilson. 2018. "I followed the flood”: A gender analysis of the moral and financial economies of forced migration.' Disasters 42 (1): S17-S39.

Lenette, Caroline and Natasa Miskovic. 2016. "'Some viewers may find the following images disturbing": Visual representations of refugee deaths at border crossings.' Crime Media Culture: an international journal 14 (1): 111-120.

Luyken, Jörg. 2016. 'Silence on sex crimes will make it worse.' The Local, 5 January. At https://www. thelocal.de/20160105/brushing-sexual-assault-under-the-carpet-is-foolish [Accessed on 18 January 2018].

Malkki, Liisa H. 1996. 'Speechless emissaries: Refugees, humanitarianism, and dehistoricization.' Cultural Anthropology 11 (3): 377-404.

Mearsheimer, John. 2001. The Tragedy of Great Power Politics. New York/London: W. W. Norton.

Mohanty, Chandra T. 1988. 'Under Western eyes: Feminist scholarship and colonial discourses.' Feminist Review 30: 61-88.

Möller, Frank. 2007. 'Photographic intervention in post-9/11 security policy.' Security Dialogue 38 (2): 179-196. 
Myrttinen, Henri, Lana Khattab and Jana Naujoks. 2017. 'Re-thinking hegemonic masculinities in conflict-affected contexts.' Critical Military Studies 2 (2): 1-17.

Pears, Louise. 2018. 'Telling terrorism tales: Narrative identity and homeland. In Dean Keen and Christine Agius (eds), The Politics of Identity: Place, Space and Discourse. Manchester: Manchester University Press, pp. 123-140.

Rajaram, Prem Kumar. 2015. 'Beyond crisis: Rethinking the population movements at Europe's border.' 19 October. At http://www.focaalblog.com/2015/10/19/prem-kumar-rajaram-beyondcrisis/\#more-1491 [Accessed on 15 January 2018].

Said, Edward. 2003 [1987]. Orientalism. London: Penguin Books.

Shaw, Eugene. 1979. 'Agenda-setting and mass communication theory'. International Communication Gazette 25 (2): 96-105.

Shepherd, Laura. 2006. 'Veiled references: Constructions of gender in the Bush administration discourse on the attacks on Afghanistan post-9/11.' International Feminist Journal of Politics 8 (1): 1941 .

2008. Gender, Violence and Security. Discourse as Practice. London: Zed Books. (ed). 2010. Gender and International Security. London/New York: Routledge.

Sommers, Marc. 2011. 'Governance, security and culture: Assessing Africa's youth bulge.' International Journal of Conflict and Violence 5 (2): 292-303.

Spivak, Gayatri C. 1988. 'Can the subaltern speak?' In Cary Nelson and Lawrence Grossberg (eds), Marxism and the Interpretation of Culture. Urbana: University of Illinois Press, pp. 271-313.

Stephen, Lynn. 2017. 'Creating preemptive suspects. National security, border defense, and immigration policy, 1980-present.' Latin American Perspectives.

Stiehm, Judith. 1982. 'The protected, the protector and the defender.' Women's Studies International Forum 5 (3/4): 367-76.

Szcepanik, Marta. 2016. 'The "good" and "bad" refugees? Imagined refugeehood(s) in the media coverage of the migration crisis.' Journal of Identity and Migration Studies 10 (2): 23-33.

Telegraph. [online]. 2015a. 'Calais crisis: Fears Isil may use migrant chaos to slip jihadists in to UK.' 24 June. At http://www.telegraph.co.uk/news/uknews/immigration/11695862/Calais-crisis-FearsIsil-may-use-migrant-chaos-to-slip-jihadists-in-to-UK.html [Accessed on 18 January 2018].

2015b. 'Each Syrian refugee to cost Britain $£ 24,000$ a year.' 19 October. At http://www.telegraph.co.uk/news/politics/11941580/Each-Syrian-refugee-to-cost-Britain-24000-a-year.html [Accessed on 18 January 2018].

. 2015c. “'Religious tensions" spark gunfight in French migrant camp.' 2 September. At http:// www.telegraph.co.uk/news/worldnews/europe/france/12124977/Religious-tensions-spark-gunfight-in-French-migrant-camp.html [Accessed on 18 January 2018].

. 2016a. 'Cologne assault: Cultural difference is no excuse for rape.' 7 January. At http://www. telegraph.co.uk/news/worldnews/europe/germany/12087780/Cologne-assault-Cultural-differenceis-no-excuse-for-rape.html [Accessed on 18 January 2018].

. 2016b. 'Europe in crisis over sex attacks by migrants amid calls for emergency EU meeting.' 8 January. At http://www.telegraph.co.uk/news/worldnews/europe/germany/12090388/Europe-incrisis-over-sex-attacks-by-migrants-amid-calls-for-emergency-EU-meeting.html [Accessed on 25 January 2018]. 
2016c. 'German women report string of sexual assaults by "Arab and North African men." 5 January. At http://www.telegraph.co.uk/news/worldnews/europe/germany/12082366/Germanwomen-report-string-of-sexual-assaults-by-Arab-and-North-African-men.html [Accessed on 18 January 2018].

2016d. 'Photo of my dead son has changed nothing', says father of drowned refugee boy Alan Kurdi.' 3 September. At http://www.telegraph.co.uk/news/2016/09/01/photo-of-my-dead-son-haschanged-nothing-says-father-of-drowned/ [Accessed on 18 January 2018].

The Guardian [online]. 2015a. 'Alan Kurdi's father on his family tragedy: "I should have died with them." 22 December. At https://www.theguardian.com/world/2015/dec/22/abdullah-kurdi-fatherboy-on-beach-alan-refugee-tragedy [Accessed on 18 January 2018].

2015b. 'Canada to turn away single men as part of Syrian refugee resettlement plan.' 23 November. At https://www.theguardian.com/world/2015/nov/23/canada-syrian-refugee-resettlementplan-no-single-men [Accessed on 18 January 2018].

2015c. 'Fattemah's choice: stay in a warzone or risk losing her baby on journey to Europe.' 23 September. At https://www.theguardian.com/world/2015/sep/23/fatimas-choice-refugee-syriawarzone-risk-losing-unborn-baby [Accessed on 18 January 2018].

. 2015d. 'This poignant photo captures the harsh reality of life for thousands of migrants. 21 August. At https:/www.theguardian.com/commentisfree/2015/aug/21/photo-migrants-laithmajid-journeys [Accessed on 18 January 2018].

. 2015e. 'Women and children arriving at Calais's migrant camps need greater protection.' 2 August. At https://www.theguardian.com/uk-news/2015/aug/02/women-children-arriving-calaismigrant-camps-greater-protection [Accessed on 18 January 2018].

The Independent [online]. 2015. 'Surprised that Syrian refugees have smartphones? Sorry to break this to you, but you're an idiot.' 7 September. At http://www.independent.co.uk/voices/comment/ surprised-that-syrian-refugees-have-smartphones-well-sorry-to-break-this-to-you-but-youre-anidiot-10489719.html [Accessed on 18 January 2018].

The Sydney Morning Herald [online]. 2015. 'The story behind the heartbreaking photo of refugee family shared by thousands.' 21 August. At http://www.smh.com.au/world/the-story-behind-theheartbreaking-photo-of-refugee-family-shared-by-thousands-20150820-gj3yi0.html [Accessed on 18 January 2018].

Tickner, J. Ann. 1992. Gender in International Relations: Feminist Perspectives on Achieving Global Security. New York: Columbia University Press.

2001. Gendering World Politics: Issues and Approaches in the Post-Cold War Era. New York: Columbia University Press.

Ticktin, Miriam I. 2011. Casualties of Care: Immigration and the Politics of Humanitarianism in France. Berkeley: University of California Press.

Time [online]. 2015. 'Are the Syrian refugees all “young, strong men”?' 20 November. At http://time. com/4122186/syrian-refugees-donald-trump-young-men/ [Accessed on 18 January 2018].

Travis, Alan. 2017. 'On asylum and refugees, Britain left Europe ages ago.' 1 March. At https://www. theguardian.com/uk-news/2017/mar/01/how-britain-hard-stance-refugees-reshaping-europeanpolicy [Accessed on 9 June 2018]. 
UNESCO. 2016. 'Correcting media myths about refugees and migrants.' At http://www.unesco. org/new/en/media-services/single-view/news/correcting_media_myths_about_refugees_and_migrants/ [accessed on 18 January 2018].

UNHCR. n.d. 'Figures at a glance.' At http://www.unhcr.org/figures-at-a-glance.html [Accessed on 5 January 2018].

2015. Global Trends: Forced Displacement in 2015. At http://www.unhcr.org/576408cd7.pdf [Accessed on 5 January 2018].

2016. 'Refugee women on the move in Europe are at risk, says UN.' 21 January. At http:// www.unhcr.org/news/latest/2016/1/569fb22b6/refugee-women-move-europe-risk-says-un.html [Accessed on 18 January 2018].

UNSC. 2000. Resolution 1325, S/RES/1325. At http://daccess-dds-ny.un.org/doc/UNDOC/GEN/ N00/720/18/PDF/N0072018.pdf?OpenElement [Accessed on 18 January 2018].

Urdal, Henrik. 2006. 'A clash of generations? Youth bulges and political violence.' International Studies Quarterly 50 (3): 607-629.

Wæver, Ole. 1995. 'Securitisation and de-securitisation'. In Ronnie Lipschutz (ed), On Security. New York: Columbia University Press, pp. 46-87.

1998. 'Security, insecurity and asecurity in the West-European non-war community'. In Emmanuel Adler and Michael Barnett (eds), Security Communities. Cambridge: Cambridge University Press, pp. 69-118.

2000. 'The EU as a security actor: Reflexions from a pessimistic constructivist on post sovereign security orders.' In Morten Kelstrup and Michael Williams (eds), International Relations Theory and the Politics of European Integration. London: Routledge, pp. 250-294.

Walt, Stephen. 1991. 'The renaissance of security studies.' International Studies Quarterly 35 (2): 211-239.

Ward, Jeanne. 2002. If Not Now, When? Addressing Gender-based Violence in Refugee Internally Displaced and Post-conflict Settings. A Global Overview. New York: The Reproductive Health for Refugees Consortium.

White, Aidan (ed). 2015. Moving Stories: International Review of How Media Cover Migration. London: Ethical Journalism Network. At http://ethicaljournalismnetwork.org/assets/docs/038/141/6adda2623eaf8d.pdf [Accessed on 5 January 2018].

Whitworth, Sandra. 2005. 'Militarized masculinities and the politics of peacekeeping: The Canadian case.' In Ken Booth (ed), Critical Security Studies in World Politics. Boulder: Lynne Rienner Publishers, pp. 89-106.

Wibben, Annick. 2011. Feminist Security Studies: A Narrative Approach. London/New York: Routledge.

\section{Acknowledgements}

This article was financed by funds from FEDER (Fundo Europeu de Desenvolvimento Regional) through the COMPETE 2020-Operacional Programme for Competitiveness and Internationalisation (POCI) and by Portuguese funds through FCT (Fundação para a Ciência e a Tecnologia) in the framework of project 029997, reference: POCI-01-0145-FEDER-029997; and by FCT in the course of Silvia Roque's post-doctoral scholarship (reference SFRH/BPD/111638/2015). 


\section{About the authors}

Rita Santos is a junior researcher at the Centre for Social Studies at the University of Coimbra (Portugal) and a member of the Humanities, Migrations and Peace Studies Group. She is a $\mathrm{PhD}$ candidate in 'International Politics and Conflict Resolution', School of Economics, University of Coimbra, and holds an MA degree in Peace Studies from the Department of Peace Studies, University of Bradford, and a BSc in International Relations, School of Economics, University of Coimbra. Her current research interests include: feminism and IR/security studies; violence, gender and small arms; the international agenda on women, peace and security and constructions of race and gender in the 'European migration crisis.'

Sílvia Roque is an FCT post-doctoral researcher at the Centre for Social Studies, University of Coimbra (Portugal), where she is also a permanent researcher in the field of Peace Studies, since 2008. She holds a PhD in International Relations and Conflict Resolution from the same university and a master's degree in African Studies from ISCTE-IUL, Lisbon. Her previous research focused on youth, gender and everyday violence in post-war countries (El Salvador and Guinea-Bissau) and her current research interests deal with the intersections between feminism, post-colonialism, memory and violence. In 2016 she published her book: Pós-guerra? Percursos de violência nas margens das Relações Internacionais (Post-war? Trajectories of violence at the margins of International Relations), published by Almedina (Coimbra).

Sofia José Santos is Assistant Professor in International Relations at the Faculty of Economics and Researcher at the Centre for Social Studies at the University of Coimbra. She is the Principal Investigator of the project '(De)Coding Masculinities: Towards an enhanced understanding of media's role in shaping perceptions of masculinities in Portugal' funded by the Portuguese Foundation for Science and Technology. Sofia holds a PhD and an MA degree in International Politics and Conflict Resolution from the University of Coimbra, a BSc degree in International Relations from the same University, and a post-graduate specialisation in Communication Sciences from ISCTE-IUL. Her current research interests relate to media and international relations; Internet, big data and societal change; and media, gender and violence. 


\title{
Des-securitizando o 'Sul no Norte'? Narrativas de Gênero no Panorama Midiático Europeu sobre os Fluxos de Refugiados
}

\begin{abstract}
Resumo: Este artigo concentra-se nas representações midiáticas do 'Sul no Norte' que perpassam mídia europeia em 2015 e início de 2016. Assumindo que as identidades, assim como as percepções de in/segurança, são socialmente construídas, particularmente por meio do discurso; que a segurança é genderificada e as construções de gênero são, por sua vez, construídas sobre as dinâmicas de in/segurança; e que as relações de poder e representações de gênero estão sempre emaranhadas com outras estruturas de desigualdade e dominação como o racismo, este artigo argumenta que as categorias genderificadas de representação de Alteridade na mídia têm sido essenciais para produzir e justificar 1) narrativas hegemônicas de securitização que visam proteger uma identidade europeia imaginada, e 2) contra-narrativas denunciando a discriminação racial e cultural ligada às representações hegemônicas 'do Norte' acerca dos refugiados. Teoricamente, o artigo propõe um diálogo entre os estudos para a paz e estudos de segurança críticos, feministas e pós-coloniais. Metodologicamente, analisa através da análise do discurso, três casos extremamente mediatizados, examinando as representações sociais dos refugiados, nomeadamente as suas dimensões de género apresentadas por meios de comunicação europeus representativos sediados no Reino Unido. Explora suas implicações em termos de consolidação de estereótipos e hierarquias de sofrimento de acordo com critérios de credibilidade/suspeita e vulnerabilidade/ameaça, e identifica alguns exemplos de contra-narrativas de mídia sobre fluxos de refugiados através de representações específicas de gênero e raciais.
\end{abstract}

Palavras-chave: Narrativas; Gênero; Raça; Identidade; Migrantes e Refugiados; Mídia; Securitização.

Received on 17 February 2018, and approved for publication on 29 August 2018.

\section{(c)) BY-NC} https://creativecommons.org/licenses/by-nc/4.0/ 